\title{
The Many Facets of SDF-1 $\alpha$, CXCR4 Agonists and Antagonists on Hematopoietic Progenitor Cells
}

\author{
Anne Faber, ${ }^{1}$ Christoph Roderburg, ${ }^{1}$ Frederik Wein, ${ }^{1}$ Rainer Saffrich, ${ }^{1}$ Anja Seckinger, ${ }^{1}$ \\ Kerstin Horsch, ${ }^{1}$ Anke Diehlmann, ${ }^{1}$ Donald Wong, ${ }^{2}$ Gary Bridger, ${ }^{3}$ Volker Eckstein, ${ }^{1}$ Anthony D. Ho, ${ }^{1}$ and \\ Wolfgang Wagner, ${ }^{1,4}$ \\ ${ }^{1}$ Department of Medicine V, University of Heidelberg, Im Neuenheimer Feld 410, 69120 Heidelberg, Germany \\ ${ }^{2}$ Chemokine Therapeutics Corporation, 6190 Agronomy Road, Vancouver, BC, Canada V6T $1 Z 3$ \\ ${ }^{3}$ AnorMED Inc., 20353 64th Avenue, Langley, BC, Canada V2Y 1N5 \\ ${ }^{4}$ Department of Physiology and Pathophysiology, University of Heidelberg, Im Neuenheimer Feld 326, 69120 Heidelberg, Germany
}

Received 20 September 2006; Revised 4 January 2007; Accepted 14 February 2007

Recommended by James L. Sherley

Stromal cell-derived factor-1alpha (SDF-1 $\alpha$ ) has pleiotropic effects on hematopoietic progenitor cells (HPCs). We have monitored podia formation, migration, proliferation, and cell-cell adhesion of human HPC under the influence of SDF-1 $\alpha$, a peptide agonist of CXCR4 (CTCE-0214), a peptide antagonist (CTCE-9908), and a nonpeptide antagonist (AMD3100). Whereas SDF-1 $\alpha$ induced migration of $\mathrm{CD}_{4} 4^{+}$cells in a dose-dependent manner, CTCE-0214, CTCE-9908, and AMD3100 did not induce chemotaxis in this concentration range albeit the peptides CTCE-0214 and CTCE-9908 increased podia formation. Cell-cell adhesion of HPC to human mesenchymal stromal cells was impaired by the addition of SDF-1 $\alpha$, CTCE-0214, and AMD3100. Proliferation was not affected by SDF- $1 \alpha$ or its analogs. Surface antigen detection of CXCR 4 was reduced upon treatment with SDF-1 $\alpha$ or AMD3100 and it was enhanced by CTCE-9908. Despite the fact that all these molecules target the same CXCR4 receptor, CXCR4 agonists and antagonists have selective effects on different functions of the natural molecule.

Copyright (c) 2007 Anne Faber et al. This is an open access article distributed under the Creative Commons Attribution License, which permits unrestricted use, distribution, and reproduction in any medium, provided the original work is properly cited.

\section{INTRODUCTION}

Stromal cell-derived factor-1 (SDF-1 or CXCL12) is a multifunctional cytokine that is constitutively expressed and secreted by several tissues, including endothelium and stromal cells $[1,2]$. It has a single open reading frame of $282 \mathrm{nu}-$ cleotides encoding a polypeptide of 93 amino acids. SDF1 arises in two forms, SDF- $1 \alpha$ (amino acids 24-88) and SDF- $1 \beta$ (amino acids 24-93), by differential splicing [3-5]. SDF- $1 \alpha$ is so far the only proven chemoattractant for primitive hematopoietic progenitor cells (HPC) [6-8]. Accordingly, SDF- $1 \alpha$ is considered as one of the key regulators for hematopoietic progenitor cell trafficking between the peripheral circulation and bone marrow [54]. Our group and others have demonstrated that SDF- $1 \alpha$ induces polarization and podia formation of HPC and leukemic cells $[9,10]$, two properties that represent prerequisites for directed locomotion. SDF- $1 \alpha$ alone showed a moderate effect on cell proliferation in $\mathrm{CD}_{3} 4^{+}$cells [11], and its effect on survival or apoptosis of HPC has remained controversial [12-15]. Fur- thermore the SDF- $1 \alpha /$ CXCR 4 axis plays a crucial role in regulation of homing and adhesion to the supportive cellular microenvironment in the stem cell niche [16].

The receptor for SDF- $1 \alpha$ has been identified as the 7transmembrane receptor CXCR4 which is also a coreceptor for the HIV type 1 virus $[17,18]$. SDF- $1 \alpha /$ CXCR4 interaction was reported to play an important role during embryonic development, especially in hematopoiesis, vascular development, and cardiogenesis. CXCR4 expression on bone marrow endothelial cells is important for internalization of circulating SDF- $1 \alpha$, resulting in its translocation into the bone marrow [2]. CXCR4 is also expressed on primitive $\mathrm{CD} 34^{+}$HPC [11]. Signal transduction pathways initiated by the binding of SDF- $1 \alpha$ to CXCR 4 are not fully understood. Mechanisms involved in CXCR4 signaling include Gi-protein-mediated activation of PI3K and the phospholipase $\mathrm{C}$ cascade $[6,19,20]$.

The function of SDF- $1 \alpha$ can be mimicked by small peptide agonists [21]. Such molecules have several advantages over the natural one such as the ease of manufacturing and 


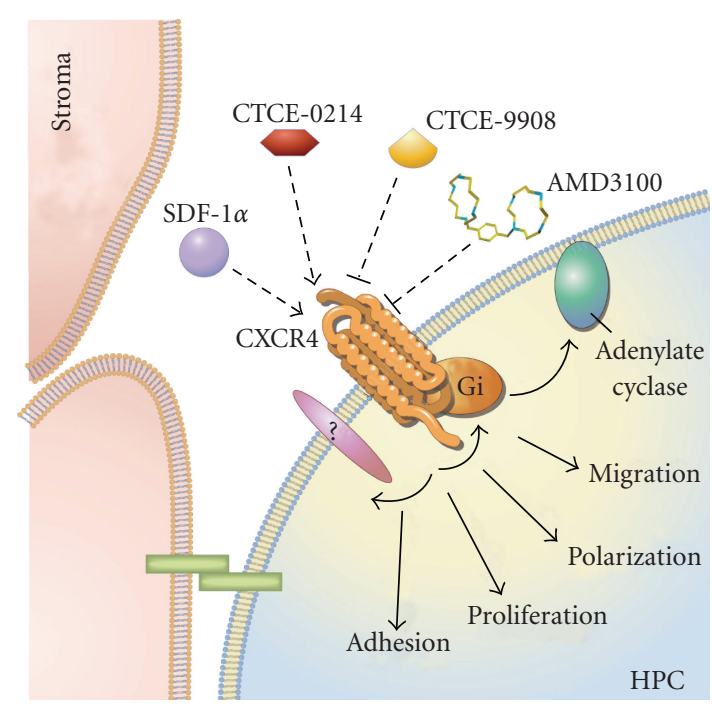

FIgURE 1: SDF- $1 \alpha /$ CXCR 4 axis and interaction with small molecules. The chemokine stromal cell-derived factor-1 alpha (SDF-1 $\alpha$ or CXCL12) is secreted by stromal cells with various effects on hematopoietic progenitor cells (HPCs). It binds to the CXCR4 receptor and this interaction can be influenced by the peptide agonist CTCE-0214 as well as by the peptide antagonists CTCE-9908 or the nonpeptide antagonist AMD3100.

that they can be more resistant to serum modification and inactivation [22]. CTCE-0214, for example, is an analog in which the C-terminal of SDF- $1 \alpha$ is connected to the $\mathrm{N}$-terminal region by a short bifunctional linker. A recent publication suggested that CTCE-0214 might improve ex vivo expansion and engraftment of HPC in a mouse model [23]. CTCE-0214 has also been reported to increase circulating HPC concentrations when administered to a murine model, indicating that this SDF- $1 \alpha$ peptide agonist could be used for mobilization [24]. CTCE-9908 is another small peptide analog that comprises a dimerized sequence of the disordered N-terminal region of SDF- $1 \alpha$ and was designed to block the CXCR4 receptor. Furthermore, nonpeptide compounds have been used to interfere with the SDF$1 \alpha /$ CXCR 4 axis. AMD3100, for example, is a bicyclam in which the two cyclam rings are tethered by an aromatic bridge. It was first designed as an inhibitor of virus replication of HIV-1 and HIV-2 [25]. However, AMD3100 has been shown to be a very potent and selective inhibitor of CXCR4 and both experimental and clinical data suggest that AMD3100 might mobilize a more primitive and hence multipotent HPC population than G-CSF $[26,27]$. The different peptide and nonpeptide analogs might have a more selective effect with respect to the different functions of the native molecule SDF- $1 \alpha$ (Figure 1). Here, we have compared effects of SDF- $1 \alpha$, CTCE-0214, CTCE-9908, and AMD3100 on polarization, migration, adhesion, proliferation, and CXCR4 receptor internalization in human CD34 cells.

\section{METHODS}

\subsection{Isolation of hematopoietic progenitor cells}

HPCs were collected from fresh umbilical cord blood after informed consent using guidelines approved by the Ethic Committee on the Use of Human Subjects at the University of Heidelberg. Mononuclear cells (MNCs) were isolated after density gradient centrifugation on Ficoll-hypaque technique (Biochrom KG, Berlin, Germany). CD $34^{+}$cells were enriched by labeling with a monoclonal anti-CD34 antibody conjugated with magnetic MICROBEADS in an AutoMACS system (Miltenyi Biotec, Bergisch-Gladbach, Germany). Further purification was achieved using the automatic cell depositing unit on an FACS-Vantage-SE flow cytometry sorting system after additional staining with antiCD34-phycoerythrin (PE) (Becton Dickinson (BD), San Jose, Calif, USA). Staining with propidium iodide (PI) was performed prior to sorting to allow exclusion of nonviable cells.

\subsection{CXCR4 agonists and antagonists}

The following analogs of SDF- $1 \alpha$ were used: SDF- $1 \alpha$ (SigmaAldrich, St. Louis, Mo, USA); CTCE-0214, peptide agonist of CXCR4 (amino acid sequence: KPVSLSYRAPFRFFLinker-LKWIQEYLEKALN) [23, 24]; CTCE-9908, peptide antagonist of CXCR4 (amino acid sequence: KGVSLSYRX-RYSLSVGK; both compounds were kindly donated by Chemokine Therapeutics Corporation, Vancouver, Canada); and AMD3100, nonpeptide antagonist of CXCR4 (courtesy of AnorMED, Langley, Canada).

\subsection{In vitro two-chamber migration assay}

Chemotaxis was assessed by a transwell-migration assay. Iscove's Modified Dulbecco's medium (IMDM; Cambrex, Walkersville, Md, USA) with 20\% FCS and different concentrations of CXCR4 agonists or antagonists as mentioned above were added to the lower chamber of a Falcon Transwell ( $3 \mu \mathrm{m}$ pore size, Becton Dickinson). Equal cell numbers were seeded in the upper chamber in medium without CXCR4 agonists or antagonists. After 2 hours, the transwells were removed and cells that had migrated through the micropores into the lower chamber were counted in a counting chamber. As the cell numbers of available $\mathrm{CD} 34^{+}$cells varied between experiments, the fold-increase of migrating cells was calculated relative to the corresponding control without cytokines.

\subsection{Cell morphology analysis by microscopy}

$\mathrm{CD}^{2} 4^{+}$cells were seeded in IMDM medium with $20 \%$ FCS with SDF-1 $\alpha$, CXCR4 agonists or antagonists for 4 hours. Cell morphology was assessed with an Olympus IX70 fluorescence microscope (Olympus Optical, Hamburg, Germany). Phase contrast pictures were taken from at least 3 regions in each well in each of five independent experiments. 
The ratio of round cells compared to polarized cells with a prominent uropod was determined.

\subsection{Cell division analysis upon CFSE staining}

$\mathrm{CD} 4^{+}$cells were labeled with carboxyfluorescein diacetate $\mathrm{N}$-succinimidyl ester (CFSE; Sigma-Aldrich, Steinheim, Germany) to monitor cell division. In brief, cells were washed in PBS with $0.1 \%$ FCS and then stained with CFSE at a final concentration of $0.3 \mu \mathrm{M}$ for 10 minutes at $37^{\circ} \mathrm{C}$. Staining reaction was stopped with ice cold RPMI with $20 \%$ FCS for 5 minutes with three subsequent washes. The labelled cells were cultured for 7 days in RPMI-1640 medium with 20\% FCS with CXCR4 agonists or antagonists $(500 \mathrm{ng} / \mathrm{mL})$ as mentioned above. Alternatively, the cells were cultured for 5 days in Myelocult (Stem Cell Technology, Vancouver, Canada) supplemented with a cytokine cocktail $(2.5 \mathrm{U} / \mathrm{mL}$ erythropoietin, $10 \mathrm{ng} / \mathrm{mL}$ interleukin-3, $500 \mathrm{U} / \mathrm{mL}$ interleukin-6, $10 \mathrm{ng} / \mathrm{mL}$ granulocyte-macrophage colony-stimulating factor, $2.5 \mathrm{ng} / \mathrm{mL}$ basic fibroblast growth factor, $10 \mathrm{ng} / \mathrm{mL}$ insulin-like growth factor-1, $50 \mathrm{ng} / \mathrm{mL}$ stem cell factor, and $2.5 \mathrm{ng} / \mathrm{mL}$ fibroblast growth factor-beta) as described previously $[28,29]$. Cells were then analyzed by flow cytometry according to their CFSE staining. Dead cells were discriminated as PI positive. The number of cell divisions could be estimated by the periodical dilution of residual CFSE dye to daughter cells.

\subsection{Adhesion assay}

Adhesive cell-cell interaction was analyzed on a feeder layer of human mesenchymal stromal cells (MSCs) from human bone marrow (BM), which were isolated in the culture medium described by Reyes et al. [30] and Wagner et al. [31, 32]. Negative control adhesion was analyzed on glass surface upon coating for 15 minutes with $10 \mathrm{ng} / \mathrm{mL}$ fibronectin (Sigma-Aldrich) or $2.5 \mathrm{~g} / \mathrm{dL}$ bovine serum albumin (BSA; PAA, Cölbe, Germany). The percentage of adherent cells was quantified with our novel adhesion assay [33]. In brief, adhesive press-to-seal silicone isolators with eight wells, $9 \mathrm{~mm}$ diameter, $1.0 \mathrm{~mm}$ deep (Invitrogen, Karlsruhe, Germany) were fixed on glass slides. Feeder layer cells were seeded in these wells in a density of about $10^{5} \mathrm{cells} / \mathrm{cm}^{2}$ and were grown for $24-72$ hours at $37^{\circ} \mathrm{C}$ and $5 \% \mathrm{CO}_{2}$ until they formed a confluent cell layer. All adhesion experiments were performed in IMDM supplemented with 20\% FCS, Penicillin $1000 \mathrm{U} / \mathrm{mL}$, and Streptomycin $100 \mathrm{U} / \mathrm{mL}$. HPCs were stained with the fluorescent membrane dye PKH26 (SigmaAldrich) before use [34-37]. About 10000 HPC were seeded per well and were allowed to settle for 15 minutes. A cover slide was sealed airtight on the silicone spacer and cells were allowed to adhere for additional 45 minutes. HPCs were then analyzed on the feeder layer cells with an Olympus IX70 fluorescence microscope (Olympus Optical, Hamburg, Germany) using a dual-band fluorescence filter set FITC/Cy3 (AHF Analysetechnik, Tübingen, Germany). The microscope was equipped with an incubation box to keep a constant temperature of $37^{\circ} \mathrm{C}$ and $5 \% \mathrm{CO}_{2}$. The experimental setting was then inverted $180^{\circ}$. Adherent cells remained attached to feeder layer cells, whereas nonadherent cells dropped down and could be observed on the focus level of the cover slide. Fluorescent images were always taken from the same region before the inversion (all cells on the feeder layer $=A L L$ ) as well as after the inversion in the focus level of feeder layer cells (adherent cells $=A D H$ ), and on the lower glass slide level (nonadherent cells $=N O N-A D H)$. Cells were counted in 36 different regions in each well. Three independent experiments were performed in duplicate with each of the SDF- $1 \alpha$ analogs, and a control without these compounds was always analyzed in parallel. Percentage of adherent cells was always calculated by two methods: (1) ADH/ALL; (2) $A D H /(A D H$ $+N O N-A D H)$, and these results were always consistent.

\subsection{Flow cytometric analysis of CXCR4}

Auto-MACS enriched CD34 ${ }^{+}$cells or BM-MSC were incubated with SDF- $1 \alpha$ analogs $(500 \mathrm{ng} / \mathrm{mL})$ for 30 minutes at $37^{\circ} \mathrm{C}$. Cells were then either washed twice with ice-cold PBS before antibody staining or the antibodies were incubated together with the SDF- $1 \alpha$ analogs. Cells were stained with anti-CXCR4-phycoerythrin (PE; clone 12G5) and antiCD34-allophycocyanin (APC) (both BD Biosciences) for additional 30 minutes at $4^{\circ} \mathrm{C}$, washed in PBS $4^{\circ} \mathrm{C}$, and immediately analyzed by flow cytometry to determine surface expression of CXCR4.

\subsection{Statistics}

All results are expressed as mean \pm standard deviation. To estimate the probability of differences, we have adopted the paired Student $t$ test. Probability value of $P<.05$ denoted statistical significance.

\section{RESULTS}

\subsection{Effects on migration}

Chemotaxis of CD34 ${ }^{+}$cells towards a gradient of SDF- $1 \alpha$ and CXCR4 agonists or antagonists was assessed in a transwell migration assay. The number of migratory cells increased continuously with the SDF- $1 \alpha$ concentration of up to $500 \mathrm{ng} / \mathrm{mL}$ SDF- $1 \alpha$ [9]. In contrast, neither the agonist CTCE-0214 nor the antagonists CTCE-9908 or AMD3100 induced any significant migration under these conditions (Figure 2(a)). However, a further increase in the concentration of CTCE-0214 $(100 \mu \mathrm{g} / \mathrm{mL})$ resulted in a moderate increase in migration of $\mathrm{CD} 34^{+}$cells.

\subsection{Effects on podia formation}

Polarization and podia formation are prerequisites for directed locomotion of HPC. We have analyzed the podia formation of $\mathrm{CD}^{+} 4^{+}$cells upon 4-hour treatment with SDF$1 \alpha$, CXCR4 agonists or CXCR4 antagonists. Consistent with our previous report $15 \%( \pm 2 \%)$ of the cells demonstrated an elongated morphology with a prominent uropod in the 


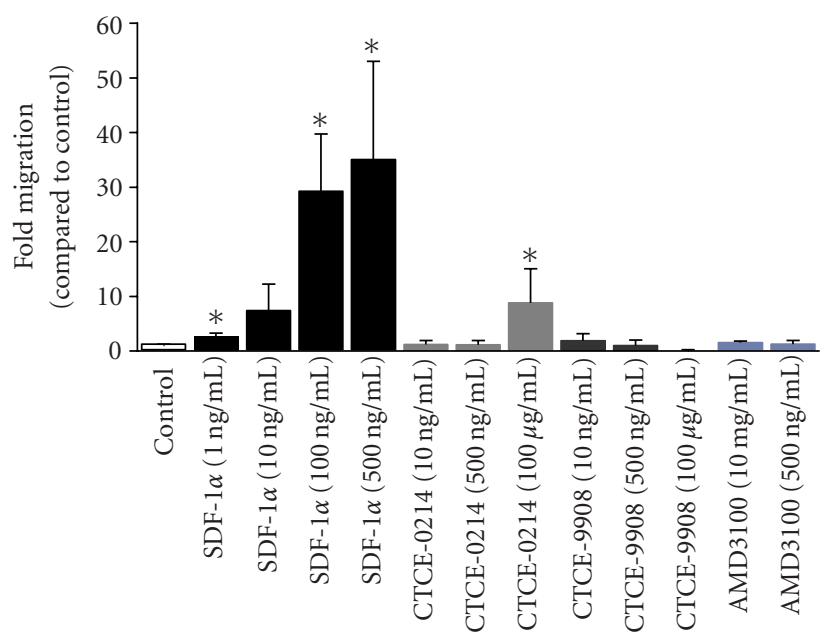

(a)

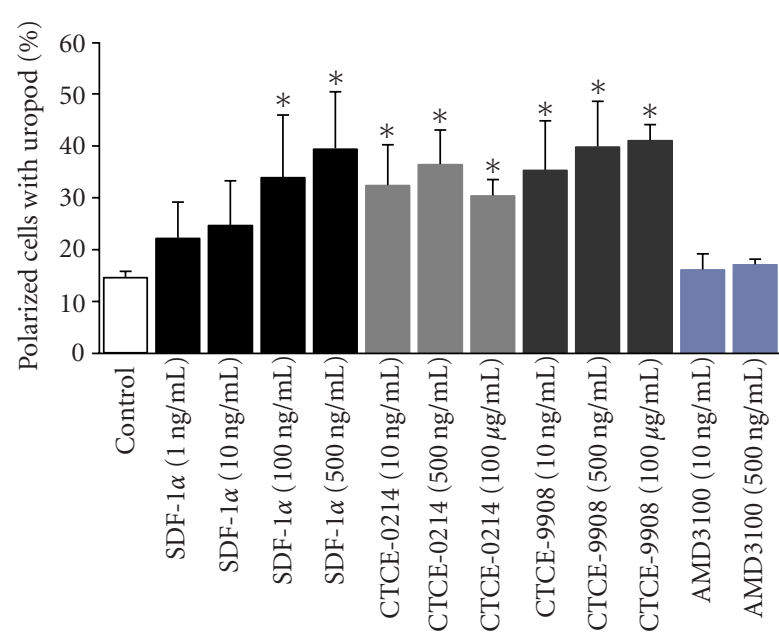

(b)

FIGURE 2: Effects on cell migration and podia formation. The effect of the SDF-1 $\alpha$, CXCR4 agonist, and CXCR4 antagonists on migration of human $\mathrm{CD}_{3} 4^{+}$cells was assessed in transwell migration experiments. The fold increase in migration upon treatment with these compounds was determined in relation to the corresponding control in four to eight independent experiments. SDF-1 $\alpha$ induced chemoattraction in a dose-dependent manner. The same concentration of the peptide agonist CTCE-0214 and the peptide antagonist CTCE-9908 did not have any significant effect on migration of $\mathrm{CD}_{3} 4^{+}$cells although there was a significant effect using much higher concentrations of CTCE-0214. (a) ${ }^{*} P<.05$. SDF- $1 \alpha$ has a dose-dependent effect on the polarization and podia formation of CD $34^{+}$cells. The morphology was analyzed in five independent experiments with simultaneous comparison of the compounds. The peptide agonist CTCE-0214 and the peptide antagonist CTCE-9908 also showed a significant effect on uropod formation. (b) $* P<.05$.

control experiments [9]. The percentage of polarized cells with a prominent uropod increased under treatment with SDF- $1 \alpha$ in a concentration-dependent manner (up to $40 \% \pm$ $10 \%$ in SDF- $1 \alpha 500 \mathrm{ng} / \mathrm{mL}$ ). Surprisingly, a significant increase in podia-forming cells was also achieved by the agonist CTCE-0214 or the antagonist CTCE-9908. Thus, these compounds might induce podia formation, probably via cytoskeletal rearrangements, but did not induce directed migration in concentrations between $10 \mathrm{ng} / \mathrm{mL}$ to $500 \mathrm{ng} / \mathrm{mL}$. AMD3100 did not affect uropod formation (Figure 2(b)).

\subsection{Effects on survival and proliferation}

$\mathrm{CD} 34^{+}$cells were cultured in a culture medium supplemented with a cytokine cocktail (Epo, IL-3, IL-6, GM-CSF, SCF, bFGF, and IGF-1) as described before [28, 29]. A high cell viability was observed and less than $1 \%$ of the cell population was PI positive upon treatment with any of the CXCR4 agonists or antagonists. Most of the cells divided up to six times after five days and cell division kinetics were not affected by the compounds (Figures 3(a) and 3(b)). Thus, we reasoned that a cytokine deprived culture condition might be more suitable for analysis of survival and proliferation. Culturing of enriched CD34 ${ }^{+}$cells in RPMI-1640 medium with $20 \%$ FCS for seven days without any supplements resulted in a reduced cell viability. According to forward scatter (FSC) and side scatter (SSC), the cell population could be clearly distinguished and represented about $30 \%$ of the counted events. About $3.1 \% \pm 0.9 \%$ of these cells were positive for propidium iodide (Figure $3(\mathrm{a})$ ). The addition of
SDF-1 $\alpha$, CTCE-0214, CTCE-9908, or AMD3100 (500 ng/mL each) did not have any significant impact on the cell number according to counted events, nor on the percentage of PI positive cells $(3.9 \% \pm 0.7 \% ; 3.0 \% \pm 0.4 \% ; 2.0 \% \pm 1.3 \%$; $3.4 \% \pm 1.2 \% ; 3.3 \% \pm 0.5 \%$, resp.). Of the remaining cells approximately $50 \%$ have divided as determined by dilution of CFSE dye. SDF- $1 \alpha$ and its analogs did not have any significant effect on proliferation of $\mathrm{CD} 34^{+}$cells although there was a tendency towards more cell divisions with CTCE-0214 (Figure 3(c)).

\subsection{Effects on adhesion}

The SDF-1 $\alpha$ /CXCR4 pathway plays a significant role in homing and mobilization of hematopoietic stem cells. Human mesenchymal stromal cells from bone marrow (BM-MSC) represent a surrogate model for studying molecular mechanisms of adhesion of human HPC towards the cellular determinants of the niche. This heterotypic cell-cell adhesion was analyzed using a novel adhesion assay [33]. By means of gravitational force, HPCs were separated into those adherent to the feeder layer and those that dropped to the original covering glass upon inversion of the culture preparations. Furthermore, we have analyzed adhesion of HPC to a protein coated glass surface without feeder layer cells. About $20 \% \pm 1 \%$ of the cells demonstrated unspecific binding to BSA and $28 \% \pm 6 \%$ remained attached to fibronectin coated surfaces [33]. In contrast, $74 \% \pm 10 \%$ of the $\mathrm{CD} 34^{+}$adhered to BM-MSC under control conditions without addition of SDF- $1 \alpha$ analogs. As demonstrated in Figure 4, there was a 

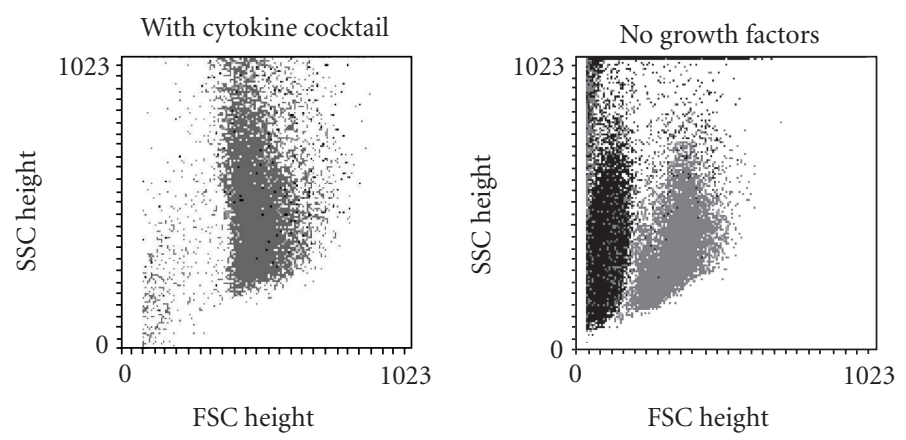

(a)
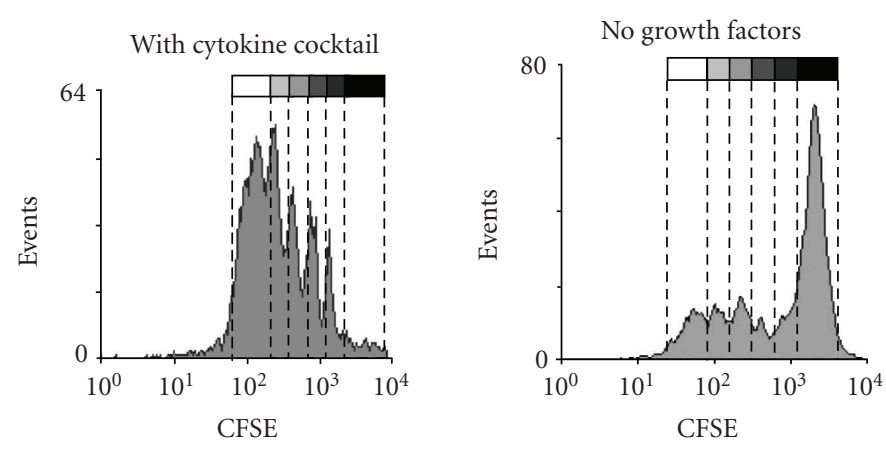

(b)
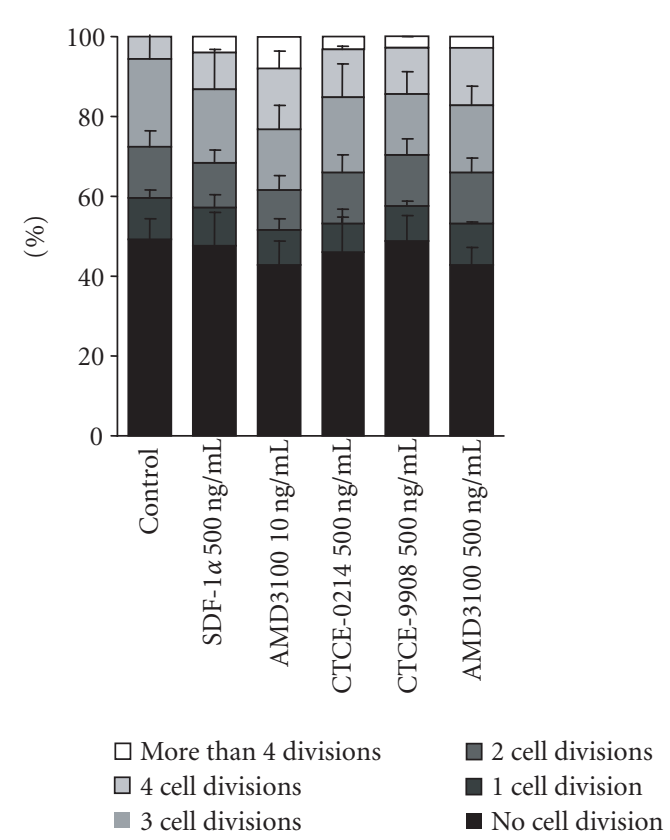

(c)

FIgUre 3: Effects on Proliferation. CD34 ${ }^{+}$cells were stained with CFSE and subsequently grown for 5 days in culture medium with a cytokine cocktail (Epo, IL-3, IL-6, GM-CSF, SCF, bFGF, and IGF-1) or for 7 days in culture medium without cytokine supplements. Cultivation with the cytokine cocktail resulted in a very high viability of $>95 \%$, whereas without cytokines the cell population could be distinguished according to forward scatter (FSC) and side scatter (SSC) from cell fragments (black spots: PI positive; grey spots: PI negative). (a) The number of cell divisions was estimated within the PI negative cell population by the dilution of CFSE dye. Whereas the CD34 ${ }^{+}$cells demonstrated a high proliferation with the cytokine cocktail, only about $50 \%$ of the cells proliferated without these cytokines. (b) SDF-1 $\alpha$, the peptide agonist CTCE-0214, the peptide antagonist CTCE-9908, and the nonpeptide antagonist AMD3100 did not have a significant effect on the fraction of proliferating cells (c) nor on the percentage of PI negative cells (three independent experiments). 


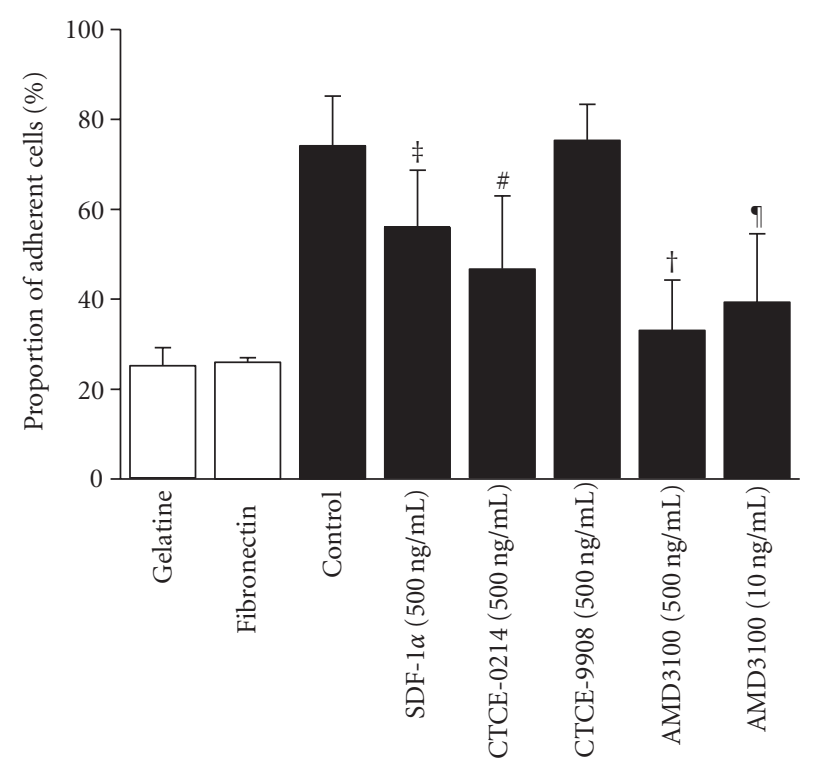

FIgURE 4: Effects on adhesion. Adhesion of $\mathrm{CD} 34^{+}$cells was either analyzed on protein-coated surfaces (white bars) or on mesenchymal stromal cells (MSCs) from human bone marrow (black bars) in culture media supplemented with SDF- $1 \alpha$, CTCE-0214, CTCE9908, or AMD3100. Adhesion was significantly reduced by SDF- $1 \alpha$, peptide agonist CTCE-0214, as well as by the mobilization agent AMD3100 (three independent experiments; ${ }^{\ddagger} P=.014 ;{ }^{\sharp} P=.007$; $\left.{ }^{\dagger} P=.7 \times 10^{-4} ;{ }^{\uparrow} P=.002\right)$.

significant reduction in cell adhesion upon treatment with SDF- $1 \alpha(55 \% \pm 13 \% ; P=.014)$, CTCE-0214 $(46 \% \pm 16 \%$; $P=.7)$ and $\operatorname{AMD} 3100\left(32 \% \pm 11 \% ; P=7 \times 10^{-5}\right)$. The peptide antagonist CTCE-9908 did not have an effect on cell adhesion $(74 \% \pm 8 \%)$.

\subsection{Effects on surface expression of CXCR4}

Various reports demonstrated that SDF- $1 \alpha$ induced internalization of the CXCR4 receptor [38-40]. In this study, we have analyzed surface expression of CXCR4 and CD34 either under treatment with CXCR4 agonists and antagonist $(n=4)$ or after two additional washing steps upon treatment with CXCR4 agonists and antagonists $(n=4)$. In four individual experiments without additional washing steps, $41.6 \% \pm 7.9 \%$ of the cells within the CD34 ${ }^{+}$fraction expressed CXCR4 on the cell surface and this proportion was even higher in the residual CD34- cells $(61.4 \% \pm 14.9 \%, P=.07)$. Pretreatment with SDF- $1 \alpha$ reduced the CXCR 4 expression within the CD $34^{+}$cells $(30.0 \% \pm 13.9 \%, P=.13)$. Detection of CXCR4 was significantly reduced upon pretreatment with AMD3100 $(6.5 \% \pm 0.8 \%, P=.002)$. The peptide agonist CTCE-0214 did not show any effect on CXCR4 expression $(43.9 \% \pm 12.9 \%)$, whereas the peptide antagonist CTCE-9908 enhanced the proportion of CXCR4 ${ }^{+}$cells $(47.0 \% \pm 6.1 \%, P=.02)$. A representative experiment of four is shown in Figure 5. Additional washing steps with ice-cold PBS to remove SDF- $1 \alpha$ agonists and antagonists prior to antibody staining revealed the same tendency, although CXCR4 detection was higher upon removal of AMD3100 (control 32.8\% \pm 3.3\%; SDF- $1 \alpha$ $20.7 \% \pm 5.2 \%, P=.06$; CTCE-0214 31.2\% \pm 5.2\%; CTCE9908 33.9\% \pm 4.7\%; AMD3100 22.5\% $\pm 6.1 \%, P=.02)$. In addition, cells were permeabilized upon treatment with the SDF- $1 \alpha$ agonists and antagonists. In the control, nearly all cells (98.45\%) were positive for CXCR4 and no decrease in CXCR4 detection was observed after cytokine stimulation.

\section{DISCUSSION}

To examine the potentials of agonists and antagonists of CXCR4, we have monitored directed migration, podia formation, adhesion behavior, and proliferation of human HPC under the influence of SDF-1 $\alpha$, a peptide agonist of CXCR4 (CTCE-0214), a peptide antagonist (CTCE-9908), and a nonpeptide antagonist (AMD3100). Despite the rationale that all of the SDF- $1 \alpha$ analogs act on the same CXCR 4 receptor, we have demonstrated that these compounds might have differential effects on different functional properties of SDF$1 \alpha$. It might be speculated that the SDF- $1 \alpha$ analogs induce different conformational changes of the CXCR4 receptor or that other coreceptors are involved. These results suggest that the signal cascade induced by SDF- $1 \alpha$ is not a monocausal succession (SDF- $1 \alpha$ binding to CXCR 4 activating G-proteins further activating downstream mediators) but rather a complex network $[6,20]$. Analysis of the downstream targets in signal cascades such as calcium flux or MAPKp42/42 activation is concurrently under way and might help to clarify some of the effects of CXCR4 agonists and antagonists.

SDF- $1 \alpha$ is a powerful chemoattactant for primitive human hematopoietic progenitor cells [20, 41, 42]. Chemotaxis of $\mathrm{CD} 4^{+}$cells can be enhanced by SDF- $1 \alpha$ in a dose-dependent manner in concentrations ranging from $0.01 \mu \mathrm{g} / \mathrm{mL}$ to $0.5 \mu \mathrm{g} / \mathrm{mL}[9,41]$. Zhong et al. have previously reported that the peptide agonist CTCE-0214 can also enhance migration of $\mathrm{CD} 34^{+}$cells in a transwell migration assay [24]. These authors used concentrations of CTCE-0214 up to $100 \mu \mathrm{g} / \mathrm{mL}$ and they described a six-fold increase in migration of $\mathrm{CD} 34^{+}$cells from mobilized peripheral blood as compared to unstimulated cells. In analogy, we observed a moderate increase in cell migration using $100 \mu \mathrm{g} / \mathrm{mL}$ CTCE0214. However, using the same concentration range as for SDF- $1 \alpha(0.01 \mu \mathrm{g} / \mathrm{mL}-0.5 \mu \mathrm{g} / \mathrm{mL})$, we demonstrated that neither CTCE-0214 nor CTCE-9908 or AMD3100 exerted significant effects on migration of $\mathrm{CD} 34^{+}$cells from umbilical cord blood. Thus, in comparison to SDF- $1 \alpha$ and on a $\mu \mathrm{g}$ to $\mu \mathrm{g}$ basis, none of the agonists and antagonists were a potent chemoattractant.

We have previously demonstrated that the primitive fraction of slow dividing cells has a higher proportion of elongated cells with a prominent uropod [28]. Furthermore, HPCs adhere to supportive feeder layer cells with their uropod at the trailing edge [37]. We and others have previously demonstrated that SDF- $1 \alpha$ affects podia formation in various AML cell lines $[9,10]$. In this study, we have shown that polarization and formation of an prominent uropod can be increased in $\mathrm{CD}_{3}{ }^{+}$cells in a dose-dependent manner by SDF- $1 \alpha$. This effect can probably be attributed to cytoskeleton rearrangements of actin-containing protrusions 

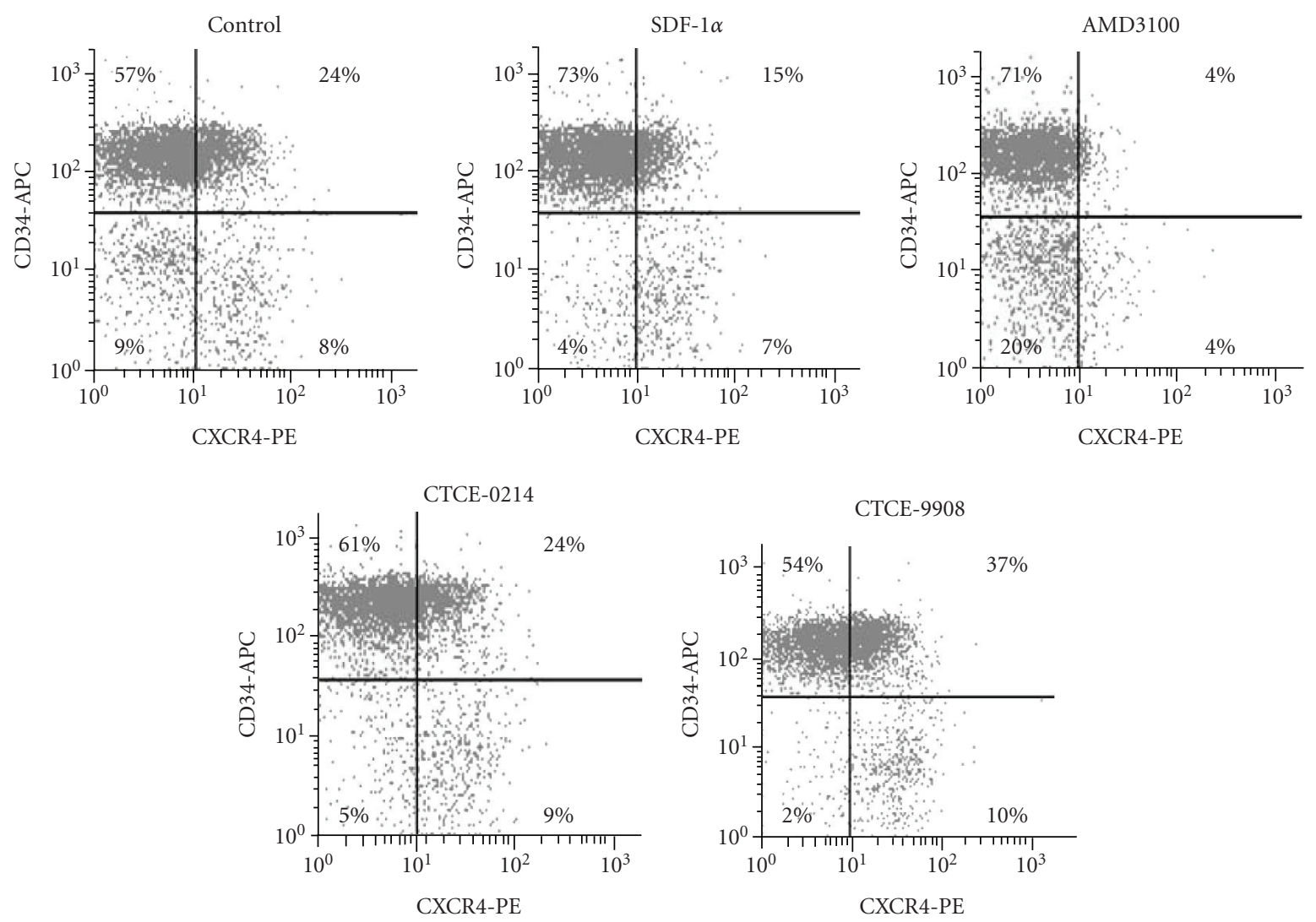

FIgURe 5: Effects on surface levels of CXCR4 detected by flow cytometry. Surface expression of CXCR4 (phycoerythrin; PE) and CD34 (allophycocyanin, APC) was analyzed on the surface of $\mathrm{CD} 34^{+}$enriched cells upon treatment with CXCR4 agonist and antagonist without additional washing steps. Demarcation of autofluorescence is indicated by black lines. The proportion of CXCR $4^{+}$cells was higher in residual CD34- cells compared to the CD34 ${ }^{+}$fraction. CXCR4 detection was reduced upon treatment with SDF-1 $\alpha$ and AMD3100. The peptide agonist CTCE-0214 did not affect the proportion of CXCR4 ${ }^{+}$cells, whereas the peptide antagonist CTCE-9908 increased this proportion. Concentration of cytokines was $500 \mathrm{ng} / \mathrm{mL}$. Representative plots of four independent experiments are shown.

[43]. Surprisingly the peptide agonist and the peptide antagonist also had a significant impact on podia formation although they did not induce directed migration. Thus, directed migration in chemotaxis does not directly correlate with podia formation.

Survival of $\mathrm{CD} 34^{+}$cells in culture could be maintained to a limited extent by cytokines such as thrombopoietin (TPO), stem cell factor (SCF), or flt-3 ligand alone or in combination. Some studies have indicated that SDF- $1 \alpha$ also might have a moderate effect on survival of $\mathrm{CD} 34^{+}$cells and this effect was significantly enhanced in combination with other cytokines [11-13, 15]. In analogy, it has been shown that CTCE-0214 alone did not increase the viability of CD34 ${ }^{+}$ cells, whereas a synergistic activity of CTCE-0214 in conjunction with other growth factors has been described [23]. In this study, we have demonstrated that neither the native molecule SDF- $1 \alpha$ nor the agonist nor the antagonists alone had a significant impact on proliferation or survival of $\mathrm{CD} 34^{+}$cells. We cannot exclude the possibility that SDF- $1 \alpha$ agonists or antagonists might induce proliferation when applied in conjunction with other chemokines as described before. It has been reported that AMD3100 was able to mobilize a CD34 ${ }^{+}$population with higher proliferative potential than upon mobilization with G-CSF [44]. These observations are most likely due to different subfractions of CD34 ${ }^{+}$cells mobilized by AMD3100 as we did not observe a significant effect of this compound on proliferation.

Human BM-MSC represents a surrogate in vitro model for studying the specific molecular mechanisms of adhesion of HPC towards the cellular niche [33]. The adhesion assay described here was used to test different compounds in parallel and it might be suitable for testing new chemical compounds that play a role on heterotypic cell-cell adhesion. We have demonstrated in this study that adhesion of CD $34^{+}$ cells to BM-MSC was significantly reduced upon treatment with SDF-1 $\alpha$, CTCE-0214, or AMD3100. In contrast, the antagonist CTCE-9908 did not affect cell adhesion. Other authors demonstrated that cell adhesion is increased by SDF- $1 \alpha$ $[43,45,46]$. However, in these studies adhesion was usually analyzed upon interaction with extracellular matrix components such as fibronectin, and nonadherent cells were separated by a washing step at one time point. In contrast, in our standardized adhesion assay without shear stress, gravitational force is affecting cell-cell interaction over a time course 
of one hour. An explanation for the increased migratory activity upon treatment with SDF- $1 \alpha$ is that cell adhesion is temporarily loosened and these cells would then detach and add to the no-adherent fraction. Furthermore, it has been reported that CXCR4 activation is also important for mediating specific migration of bone marrow stromal cells although this receptor seems to be only present at very low levels at the surface of MSC [47-49]. Thus, in contrast to previous studies that analyzed adhesion of HSC to fibronectin, we have analyzed adhesion to MSC with and without the addition of SDF- $1 \alpha$, its agonists, and antagonists. Our results are compatible with the observation that both agonist and antagonists of the SDF-1 $\alpha /$ CXCR4 axis have been shown to effectively mobilize primitive HPC to the peripheral blood. Elevated plasma levels of SDF- $1 \alpha$ induce mobilization of HPC to the peripheral blood [16]. In the murine system, injection of CTCE-0214 led to an increase of primitive HPC in the peripheral blood [24]. AMD3100 has been reported to mobilize HSC from the bone marrow to peripheral blood efficiently [26]. The increase of HPC is rapid after a single injection and the corresponding clinical trials have been conducted successfully in patients who have failed to respond to granulocyte colony stimulating factors alone.

In our previous work, we provided evidence that more primitive fractions of HPC adhere significantly more than their more differentiated counterparts $\left(\mathrm{CD} 34^{+}\right.$versus CD $34^{-}, \mathrm{CD}_{3}{ }^{+} \mathrm{CD} 38^{-}$versus $\mathrm{CD} 34^{+} \mathrm{CD} 38^{+}$, slow dividing fraction versus fast dividing fraction of $\mathrm{CD} 34^{+} \mathrm{CD} 38^{-}$cells) [33]. Furthermore, there is evidence that AMD3100 and GCSF might mobilize a more primitive and hence multipotent HPC population than G-CSF alone [26, 27]. Thus, it could be speculated that CXCR4 agonists and antagonists affect the specific interaction of primitive HPCs and their cellular microenvironment.

The proportion of $\mathrm{CXCR} 4^{+} / \mathrm{CD} 34^{+}$cells was reduced upon stimulation with SDF- $1 \alpha$ and AMD3100. Buul et al. have previously demonstrated that SDF- $1 \alpha$ induced redistribution and internalization of a CXCR4-fusion protein in KGla cells [38]. This phenomenon has also been shown for other leukemic cell lines [40]. Dar et al. reported that CXCR4-dependent internalization of and resecretion of SDF- $1 \alpha$ by endothelial and stromal cells played an essential role to establish an SDF- $1 \alpha$ gradient that assisted directed migration of $\mathrm{CD}_{4}{ }^{+}$cells [2]. Multiple residues within the CXCR4 C-terminal tail appeared to mediate this receptor internalization [39]. In this context, our data have provided evidence that CXCR4 is also internalized in $\mathrm{CD}_{3} 4^{+}$cells upon stimulation with SDF- $1 \alpha$. Hatse et al. reported long-term interaction of AMD3100 with CXCR4 that blocked binding of the same antibody (clone 12G5) at the cell membrane [50]. Furthermore, they described that AMD3100 inhibits SDF$1 \alpha$-induced internalization of CXCR4 in U87-CD4 cells. This is in line with our observation that CXCR4 surface detection by the $12 \mathrm{G} 5$ antibody is abolished by AMD3100, whereas additional washing steps increased the detection of CXCR4. Thus, further analysis of internalized receptor revealed no effect of AMD3100 treatment on intracellular CXCR4 detection. On the other hand, our results provide evidence that
CTCE-0214 does not affect receptor internalization, whereas the peptide antagonist CTCE-9908 enhanced the proportion of CXCR4 ${ }^{+}$cells, and this observation is compatible with reduced receptor internalization. The G-protein coupled receptor CXCR4 is not an adhesion protein itself. However, recently crosstalk between the CXCR4/SDF- $1 \alpha$ axis and other adhesion proteins such as VLA-4, VLA-5, and CD164 has been shown [51], and hence internalization of CXCR4 upon stimulation with agonists and antagonists might be associated with redistribution of these adhesion proteins, and thereby reducing intercellular adhesion.

Peptide and nonpeptide analogs have several advantages compared to the native molecules. The ease of synthesis, lower manufacturing costs, improved bioavailability, and lower immunogenicity of peptides or analogs may make them more accessible for clinical applications. Recent results have also suggested that the SDF- $1 \alpha /$ CXCR 4 axis is also used by cancer cells for metastatic dissemination in many types of solid tumours $[52,53]$. In addition to mobilization of HPC, CXCR4 agonists and antagonists might have the potential for treatment of metastatic diseases. If confirmed, precise knowledge of homing and adhesion and their specific manipulation might have significant therapeutic potentials and implications.

\section{ACKNOWLEDGMENTS}

We would like to thank Ms. Katrin Miesala for excellent technical assistance in cell culture and Christopher Schwab for the artwork of Figure 1. This work was supported by the German Ministry of Education and Research (BMBF) within the National Genome Research Network NGFN-2 (EP-S19T01) and within the Supporting Program "Cell-Based Regenerative Medicine" (START-MSC), the German Research Foundation DFG (HO 914/2-3), and the Joachim SiebeneicherStiftung, Germany. A. Faber and C. Roderburg contributed equally to this paper. The author of correspondence is professor A. D. Ho.

\section{REFERENCES}

[1] K. Imai, M. Kobayashi, J. Wang, et al., "Selective secretion of chemoattractants for haemopoietic progenitor cells by bone marrow endothelial cells: a possible role in homing of haemopoietic progenitor cells to bone marrow," British Journal of Haematology, vol. 106, no. 4, pp. 905-911, 1999.

[2] A. Dar, P. Goichberg, V. Shinder, et al., "Chemokine receptor CXCR4-dependent internalization and resecretion of functional chemokine SDF-1 by bone marrow endothelial and stromal cells," Nature Immunology, vol. 6, no. 10, pp. 10381046, 2005.

[3] M. Shirozu, T. Nakano, J. Inazawa, et al., "Structure and chromosomal localization of the human stromal cell-derived factor 1 (SDF1) gene," Genomics, vol. 28, no. 3, pp. 495-500, 1995.

[4] T. Shioda, H. Kato, Y. Ohnishi, et al., "Anti-HIV-1 and chemotactic activities of human stromal cell-derived factor $1 \alpha$ (SDF$1 \alpha$ ) and SDF-1 $\beta$ are abolished by CD26/dipeptidyl peptidase IV-mediated cleavage," Proceedings of the National Academy of Sciences of the United States of America, vol. 95, no. 11, pp. 6331-6336, 1998. 
[5] S. M. de La Luz, F. Yang, M. Narazaki, et al., "Differential processing of stromal-derived factor- $1 \alpha$ and stromal-derived factor- $1 \beta$ explains functional diversity," Blood, vol. 103, no. 7, pp. 2452-2459, 2004.

[6] I. Petit, P. Goichberg, A. Spiegel, et al., "Atypical PKC- $\zeta$ regulates SDF-1-mediated migration and development of human CD $34^{+}$progenitor cells," Journal of Clinical Investigation, vol. 115, no. 1, pp. 168-176, 2005.

[7] R. Möhle, F. Bautz, S. Rafii, M. A. S. Moore, W. Brugger, and L. Kanz, "The chemokine receptor CXCR-4 is expressed on $\mathrm{CD} 34^{+}$hematopoietic progenitors and leukemic cells and mediates transendothelial migration induced by stromal cellderived factor-1," Blood, vol. 91, no. 12, pp. 4523-4530, 1998.

[8] C. H. Kim and H. E. Broxmeyer, "In vitro behavior of hematopoietic progenitor cells under the influence of chemoattractants: stromal cell-derived factor-1, steel factor, and the bone marrow environment," Blood, vol. 91, no. 1, pp. 100-110, 1998.

[9] S. Fruehauf, K. Srbic, R. Seggewiss, J. Topaly, and A. D. Ho, "Functional characterization of podia formation in normal and malignant hematopoietic cells," Journal of Leukocyte Biology, vol. 71, no. 3, pp. 425-432, 2002.

[10] S. Tavor, I. Petit, S. Porozov, et al., "Motility, proliferation, and egress to the circulation of human AML cells are elastase dependent in NOD/SCID chimeric mice," Blood, vol. 106, no. 6, pp. 2120-2127, 2005.

[11] J.-J. Lataillade, D. Clay, C. Dupuy, et al., "Chemokine SDF-1 enhances circulating CD $34^{+}$cell proliferation in synergy with cytokines: possible role in progenitor survival," Blood, vol. 95, no. 3, pp. 756-768, 2000.

[12] J.-J. Lataillade, D. Clay, P. Bourin, et al., "Stromal cell-derived factor 1 regulates primitive hematopoiesis by suppressing apoptosis and by promoting $\mathrm{G}_{0} / \mathrm{G}_{1}$ transition in $\mathrm{CD} 34^{+}$ cells: evidence for an autocrine/paracrine mechanism," Blood, vol. 99, no. 4, pp. 1117-1129, 2002.

[13] Y. Lee, A. Gotoh, H.-J. Kwon, et al., "Enhancement of intracellular signaling associated with hematopoietic progenitor cell survival in response to SDF-1/CXCL12 in synergy with other cytokines," Blood, vol. 99, no. 12, pp. 4307-4317, 2002.

[14] J. Kijowski, M. Baj-Krzyworzeka, M. Majka, et al., "The SDF1-CXCR4 axis stimulates VEGF secretion and activates integrins but does not affect proliferation and survival in lymphohematopoietic cells," Stem Cells, vol. 19, no. 5, pp. 453-466, 2001.

[15] H. E. Broxmeyer, L. Kohli, C. H. Kim, et al., "Stromal cell-derived factor-1/CXCL12 directly enhances survival/antiapoptosis of myeloid progenitor cells through CXCR4 and G $\alpha$ i proteins and enhances engraftment of competitive, repopulating stem cells," Journal of Leukocyte Biology, vol. 73, no. 5, pp. 630-638, 2003.

[16] K. Hattori, B. Heissig, K. Tashiro, et al., "Plasma elevation of stromal cell-derived factor-1 induces mobilization of mature and immature hematopoietic progenitor and stem cells," Blood, vol. 97, no. 11, pp. 3354-3360, 2001.

[17] C. C. Bleul, M. Farzan, H. Choe, et al., "The lymphocyte chemoattractant SDF-1 is a ligand for LESTR/fusin and blocks HIV-1 entry," Nature, vol. 382, no. 6594, pp. 829-833, 1996.

[18] J.-I. Yamaguchi, K. F. Kusano, O. Masuo, et al., "Stromal cellderived factor- 1 effects on ex vivo expanded endothelial progenitor cell recruitment for ischemic neovascularization," Circulation, vol. 107, no. 9, pp. 1322-1328, 2003.

[19] J.-F. Wang, I.-W. Park, and J. E. Groopman, "Stromal cellderived factor- $1 \alpha$ stimulates tyrosine phosphorylation of multiple focal adhesion proteins and induces migration of hematopoietic progenitor cells: roles of phosphoinositide-3 kinase and protein kinase C," Blood, vol. 95, no. 8, pp. 25052513, 2000.

[20] P. Goichberg, A. Kalinkovich, N. Borodovsky, et al., "cAMPinduced PKC- $\zeta$ activation increases functional CXCR4 expression on human $\mathrm{CD}_{3} 4^{+}$hematopoietic progenitors," Blood, vol. 107, no. 3, pp. 870-879, 2006.

[21] C. Tudan, G. E. Willick, S. Chahal, et al., "C-terminal cyclization of an SDF-1 small peptide analogue dramatically increases receptor affinity and activation of the CXCR4 receptor," Journal of Medicinal Chemistry, vol. 45, no. 10, pp. 20242031, 2002.

[22] S. Villalba, O. Salvucci, Y. Aoki, et al., "Serum inactivation contributes to the failure of stromal-derived factor-1 to block HIV-1 infection in vivo," Journal of Leukocyte Biology, vol. 74, no. 5, pp. 880-888, 2003.

[23] K. Li, C. K. Y. Chuen, S. M. Lee, et al., "Small peptide analogue of SDF- $1 \alpha$ supports survival of cord blood CD34 ${ }^{+}$cells in synergy with other cytokines and enhances their ex vivo expansion and engraftment into nonobese diabetic/severe combined immunodeficient mice," Stem Cells, vol. 24, no. 1, pp. 55-64, 2006.

[24] R. Zhong, P. Law, D. Wong, A. Merzouk, H. Salari, and E. D. Ball, "Small peptide analogs to stromal derived factor1 enhance chemotactic migration of human and mouse hematopoietic cells," Experimental Hematology, vol. 32, no. 5, pp. 470-475, 2004.

[25] E. de Clercq, "Potential clinical applications of the CXCR4 antagonist bicyclam AMD3100," Mini-Reviews in Medicinal Chemistry, vol. 5, no. 9, pp. 805-824, 2005.

[26] H. E. Broxmeyer, C. M. Orschell, D. W. Clapp, et al., "Rapid mobilization of murine and human hematopoietic stem and progenitor cells with AMD3100, a CXCR4 antagonist," Journal of Experimental Medicine, vol. 201, no. 8, pp. 1307-1318, 2005.

[27] S. Fruehauf, T. Seeger, P. Maier, et al., "The CXCR4 antagonist AMD3100 releases a subset of G-CSF-primed peripheral blood progenitor cells with specific gene expression characteristics," Experimental Hematology, vol. 34, no. 8, pp. 1052-1059, 2006.

[28] W. Wagner, A. Ansorge, U. Wirkner, et al., "Molecular evidence for stem cell function of the slow-dividing fraction among human hematopoietic progenitor cells by genomewide analysis," Blood, vol. 104, no. 3, pp. 675-686, 2004.

[29] S. Huang, P. Law, K. Francis, B. O. Palsson, and A. D. Ho, "Symmetry of initial cell divisions among primitive hematopoietic progenitors is independent of ontogenic age and regulatory molecules," Blood, vol. 94, no. 8, pp. 25952604, 1999.

[30] M. Reyes, T. Lund, T. Lenvik, D. Aguiar, L. Koodie, and C. M. Verfaillie, "Purification and ex vivo expansion of postnatal human marrow mesodermal progenitor cells," Blood, vol. 98, no. 9, pp. 2615-2625, 2001.

[31] W. Wagner, F. Wein, A. Seckinger, et al., "Comparative characteristics of mesenchymal stem cells from human bone marrow, adipose tissue, and umbilical cord blood," Experimental Hematology, vol. 33, no. 11, pp. 1402-1416, 2005.

[32] W. Wagner, R. E. Feldmann Jr., A. Seckinger, et al., "The heterogeneity of human mesenchymal stem cell preparations Evidence from simultaneous analysis of proteomes and transcriptomes," Experimental Hematology, vol. 34, no. 4, pp. 536548, 2006.

[33] W. Wagner, F. Wein, C. Roderburg, et al., "Adhesion of hematopoietic progenitor cells to human mesenchymal 
stromal cells as a model for cell-cell interaction," Experimental Hematology, vol. 35, no. 2, pp. 314-325, 2007.

[34] W. Holloway, A. R. Martinez, D. J. Oh, K. Francis, R. Ramakrishna, and B. O. Palsson, "Key adhesion molecules are present on long podia extended by hematopoietic cells," Cytometry, vol. 37, no. 3, pp. 171-177, 1999.

[35] D. J. Oh, A. R. Martinez, G. M. Lee, K. Francis, and B. O. Palsson, "Intercellular adhesion can be visualized using fluorescently labeled fibrosarcoma HT1080 cells cocultured with hematopoietic cell lines or $\mathrm{CD} 34^{+}$enriched human mobilized peripheral blood cells," Cytometry, vol. 40, no. 2, pp. 119-125, 2000.

[36] A. E. Frimberger, C. I. McAuliffe, K. A. Werme, et al., "The fleet feet of haematopoietic stem cells: rapid motility, interaction and proteopodia," British Journal of Haematology, vol. 112, no. 3, pp. 644-654, 2001.

[37] W. Wagner, R. Saffrich, U. Wirkner, et al., "Hematopoietic progenitor cells and cellular microenvironment: behavioral and molecular changes upon interaction," Stem Cells, vol. 23, no. 8, pp. 1180-1191, 2005.

[38] J. D. van Buul, C. Voermans, J. van Gelderen, E. C. Anthony, C. E. van der Schoot, and P. L. Hordijk, "Leukocyteendothelium interaction promotes SDF-1-dependent polarization of CXCR4," Journal of Biological Chemistry, vol. 278, no. 32, pp. 30302-30310, 2003.

[39] M. J. Orsini, J.-L. Parent, S. J. Mundell, J. L. Benovic, and A. Marchese, "Trafficking of the HIV coreceptor CXCR4. Role of arrestins and identification of residues in the c-terminal tail that mediate receptor internalization," Journal of Biological Chemistry, vol. 274, no. 43, pp. 31076-31086, 1999.

[40] A. Sachpatzidis, B. K. Benton, J. P. Manfredi, et al., "Identification of allosteric peptide agonists of CXCR4," Journal of Biological Chemistry, vol. 278, no. 2, pp. 896-907, 2003.

[41] A. Aiuti, I. J. Webb, C. Bleul, T. Springer, and J. C. GutierrezRamos, "The chemokine SDF-1 is a chemoattractant for human $\mathrm{CD}_{3} 4^{+}$hematopoietic progenitor cells and provides a new mechanism to explain the mobilization of CD $34^{+}$progenitors to peripheral blood," Journal of Experimental Medicine, vol. 185, no. 1, pp. 111-120, 1997.

[42] D. E. Wright, E. P. Bowman, A. J. Wagers, E. C. Butcher, and I. L. Weissman, "Hematopoietic stem cells are uniquely selective in their migratory response to chemokines," Journal of Experimental Medicine, vol. 195, no. 9, pp. 1145-1154, 2002.

[43] A. Avigdor, P. Goichberg, S. Shivtiel, et al., "CD44 and hyaluronic acid cooperate with SDF-1 in the trafficking of human $\mathrm{CD}^{+} 4^{+}$stem/progenitor cells to bone marrow," Blood, vol. 103, no. 8, pp. 2981-2989, 2004.

[44] A. Larochelle, A. Krouse, M. Metzger, et al., "AMD3100 mobilizes hematopoietic stem cells with long-term repopulating capacity in nonhuman primates," Blood, vol. 107, no. 9, pp. 3772-3778, 2006.

[45] S. Basu and H. E. Broxmeyer, "Transforming growth factor- $\beta 1$ modulates responses of $\mathrm{CD} 34^{+}$cord blood cells to stromal cellderived factor-1/CXCL12," Blood, vol. 106, no. 2, pp. 485-493, 2005.

[46] N. Wright, T. L. de Lera, C. García-Moruja, et al., “Transforming growth factor- $\beta 1$ down-regulates expression of chemokine stromal cell-derived factor-1: functional consequences in cell migration and adhesion,” Blood, vol. 102, no. 6, pp. 19781984, 2003.

[47] R. F. Wynn, C. A. Hart, C. Corradi-Perini, et al., "A small proportion of mesenchymal stem cells strongly expresses functionally active CXCR4 receptor capable of promoting migra- tion to bone marrow," Blood, vol. 104, no. 9, pp. 2643-2645, 2004.

[48] S. Bhakta, P. Hong, and O. Koc, "The surface adhesion molecule CXCR4 stimulates mesenchymal stem cell migration to stromal cell-derived factor-1 in vitro but does not decrease apoptosis under serum deprivation," Cardiovascular Revascularization Medicine, vol. 7, no. 1, pp. 19-24, 2006.

[49] B.-R. Son, L. A. Marquez-Curtis, M. Kucia, et al., "Migration of bone marrow and cord blood mesenchymal stem cells in vitro is regulated by stromal-derived factor-1-CXCR4 and hepatocyte growth factor-c-met axes and involves matrix metalloproteinases," Stem Cells, vol. 24, no. 5, pp. 1254-1264, 2006.

[50] S. Hatse, K. Princen, K. Vermeire, et al., "Mutations at the CXCR4 interaction sites for AMD3100 influence anti-CXCR4 antibody binding and HIV-1 entry," FEBS Letters, vol. 546, no. 2-3, pp. 300-306, 2003.

[51] S. P. Forde, T. B. Jorgensen, S. E. Newey, et al., "Endolyn (CD164) modulates the CXCL12-mediated migration of umbilical cord blood CD133 ${ }^{+}$cells," Blood, vol. 109, no. 5, pp. 1825-1833, 2007.

[52] D. A. Sipkins, X. Wei, J. W. Wu, et al., "In vivo imaging of specialized bone marrow endothelial microdomains for tumour engraftment," Nature, vol. 435, no. 7044, pp. 969-973, 2005.

[53] J. A. Burger and T. J. Kipps, "CXCR4: a key receptor in the crosstalk between tumor cells and their microenvironment," Blood, vol. 107, no. 5, pp. 1761-1767, 2006.

[54] J. P. Chute, "Stem cell homing," Current Opinion in Hematology, vol. 13, no. 6, pp. 399-406, 2006. 

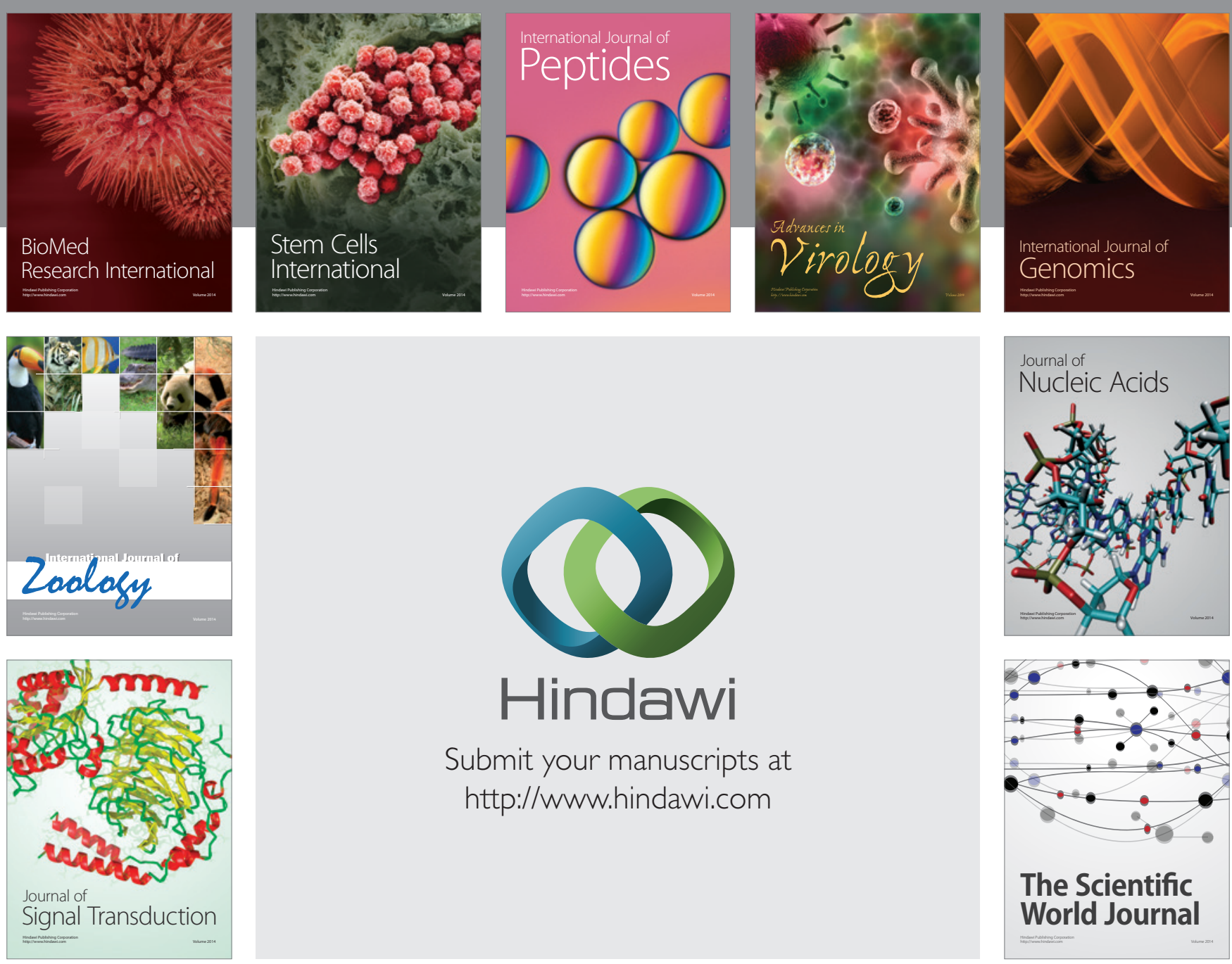

Submit your manuscripts at

http://www.hindawi.com
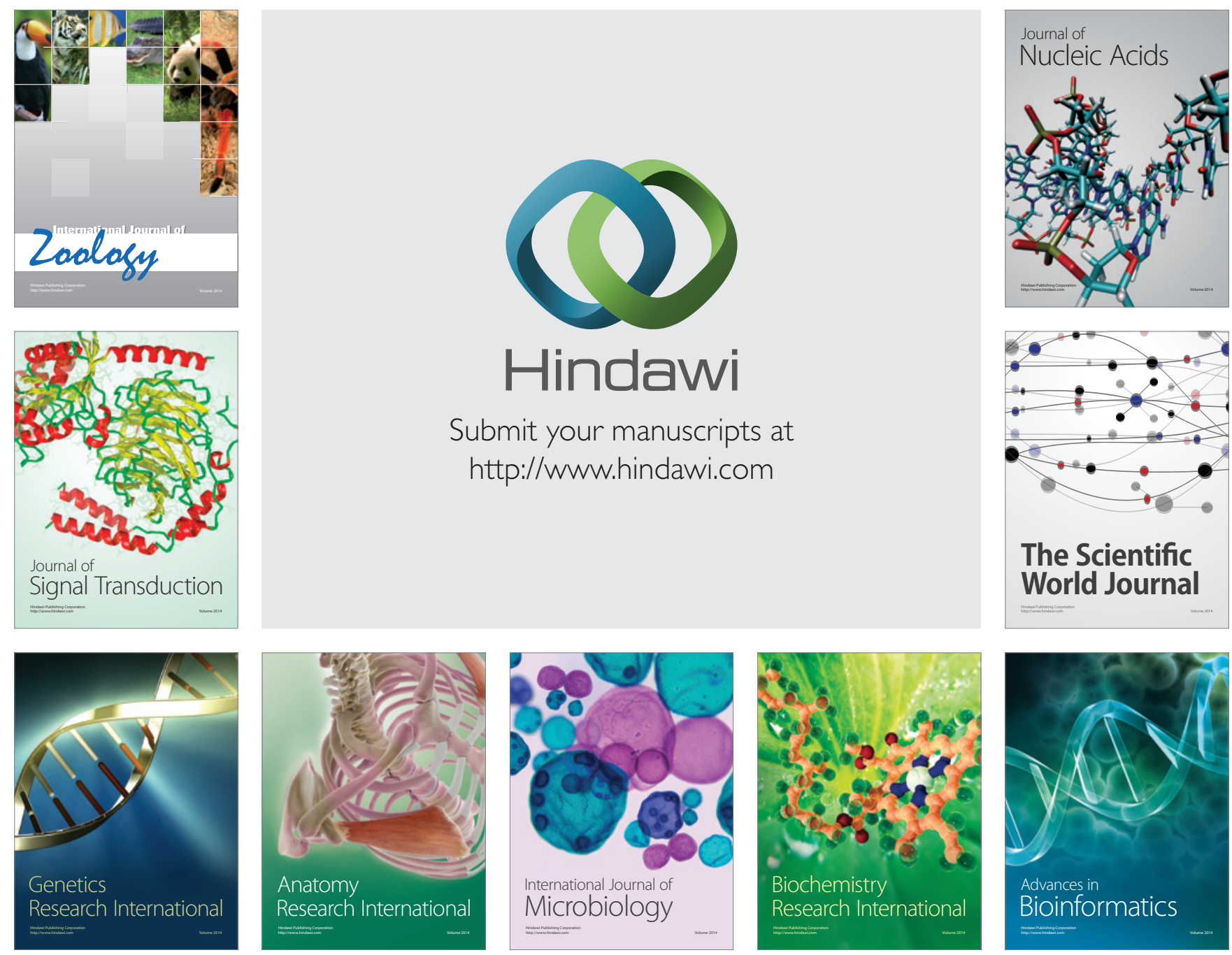

The Scientific World Journal
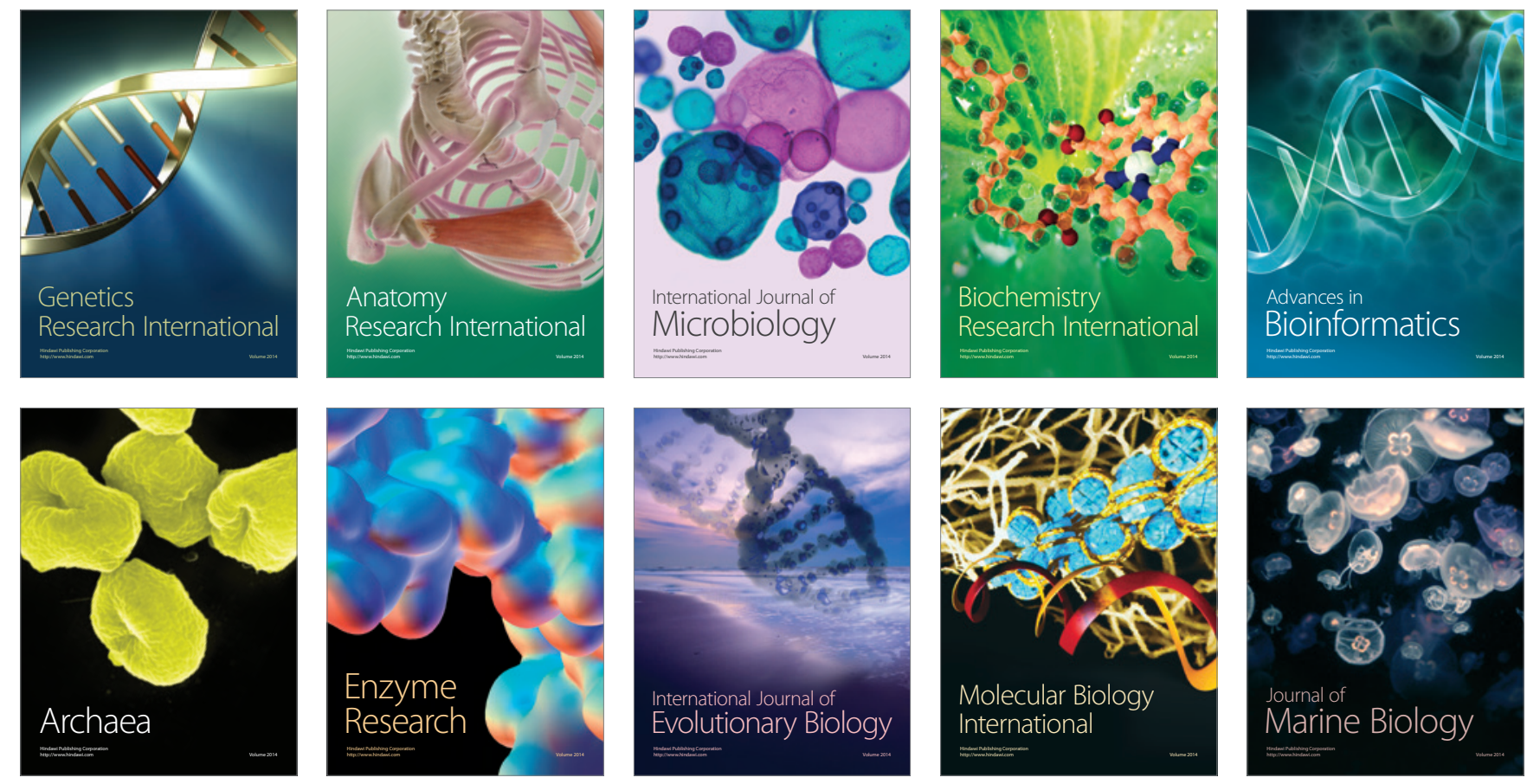